\title{
Performance of Islamic Microfinance Banks: The Case of a Developing Country
}

\section{Taufik Akbar ${ }^{1}$ and A.K Siti Nabiha²}

${ }^{1}$ Graduate School of Business, Universiti Sains Malaysia 11800 Penang, Malaysia 1, Universitas Mercu Buana, 11650 West Jakarta, Indonesia

${ }^{2}$ Graduate School of Business, Universiti Sains Malaysia 11800 Penang, Malaysia

\section{Abstract}

Similar to conventional microfinance banks institutions, Islamic microfinance banks provide intermediary financial services by receiving funds from investors and other stakeholders and disbursing funds to micro, small and medium-sized entrepreneurs and poor households. Islamic microfinance banks play a significant role in developing countries, especially in Indonesia. However, Islamic microfinance banks have not experienced significant growth and achieved good performance as expected. The paper thus investigates Indonesian Islamic microfinance banks performance in comparison to conventional microfinance banks. The data from the Indonesian Services

Corresponding Author:

Taufik Akbar

taufikakbarakt@gmail.com

Received: 5 August 2019

Accepted: 14 August 2019

Published: 18 August 2019

Publishing services provided by Knowledge E

(c) Taufik Akbar and A.K Siti Nabiha. This article is distributed under the terms of the

which permits unrestricted use and redistribution provided that the original author and source are credited.

Selection and Peer-review under the responsibility of the FGIC2019 Conference Committee.

\section{G OPEN ACCESS}

Authority (OJK) were analyzed from 2012 to 2017. The findings showed that Islamic microfinance banks had performed poorly as compared to conventional microfinance banks. Suggestions for further empirical investigation were made to ascertain the reasons for such poor performance.

Keywords: islamic microfinance banks, performance of islamic microfinance banks, indonesia, developing country.

\section{Introduction}

Microfinance institution (MFIs) is the provision of various financial services including credits, insurance, savings, deposits, and payment services to poor, low-income households, and micro or small businesses that are financially excluded due to the lack of collateral (Ledgerwood, 1999; Littlefield, Morduch, \& Hashemi, 2003; Robinson, 2001; Abdelkader \& Salem, 2013; Begum, Alam, Mia, Bhuiyan, \& Ghani, 2018; Berguiga et al., 2017; Hermes \& Hudon, 2018; Reichert, 2018; Wediawati et al., 2018). In particular, MFIs differ from traditional financial institutions due to the existence of double bottom-line objectives for serving poor customers (outreach) and financial sustainability (Tulchin, 2003). Hence, MFIs are the financial institutions that serve as an intermediary whose purpose is not merely to seek profits but also to realize social goals such as community development (Baskara, 2013). Islamic Microfinance Institution (IMFIs) was established to cater to the needs of the Muslim community as it supposed to operate based 
on the Sharia principles. IMFIs reflects the confluence of two fast-growing industries, microfinance, and Islamic finance. Microfinance is as an essential tool in supporting and strengthening the economy at the bottom of the socio-economic pyramid by facilitating access to financial services for the poorest and the destitute, while Islamic finance is a financial system based on Sharia principles. The strict prohibition of paying or receiving any fixed interest (riba) is the most widely known characteristic of this financial system (CGPA, 2013; Abdelkader \& Salem, 2013; Mobin et al., 2017). The purpose of IMFIs is similar to conventional MFIs in terms of providing services to financially excluded, hence it needs to achieve a social objective while at the same time being financially sustainable (Abdelkader \& Salem, 2013; Hermes \& Hudon, 2018; Mobin, Masih, \& Alhabshi, 2017;Tulchin, 2003;CGPA, 2013; Murdock, 1999). IMFIs' financial and social performance is not satisfactory compared to conventional MFIs. The CGAP survey in 2007 showed that Bangladesh, a country with the largest microfinance coverage in the world with almost 8 million microfinance lenders, has an Islamic microfinance coverage of only 1 percent or around 100,000 clients. In Syria and Indonesia, the figures contribute 3 percent and 2 percent of the microcredit value respectively in 2006 (Karim, Tarazi \& Reille, 2008). Therefore, it is indicated that Indonesia Sharia microfinance showed low financial and social performance even though Indonesia is the largest Muslim country with total followers around 207,176,162 people but it is unable to make IMFIs performance grow and develop (Risfandy, Husa, \& Asrihapsari, 2016; Central Bureau of Statistics, 2018). Hence, this paper investigates the recent financial and social performance of formal IMFIs and compared their performance to the conventional MFIs and to suggest avenues for further research in this area.

\section{Microfinance Institutions in Indonesia}

Indonesia has both conventional and Islamic microfinance institutions. The MFIs in Indonesia are regulated by Law No. 1 of 2013 which stipulates that microfinance is a financial institution purposively established to provide business development and community empowerment services, either through loans or financing to micro-scale businesses and community members, deposit management, and to provide business development consulting services that are not profit-oriented based on conventional or Islamic principle. Hence, MFIs are the financial institutions that serve as an intermediary whose purpose is not merely to seek profits but also to realize social goals such as community development (Baskara, 2013). Microfinance programs in Indonesia are managed by formal, semi-formal, and informal institutions. Formal microfinance institutions 
are those that are regulated under the Indonesian banking law, and Financial Services Authority of Indonesia (OJK). The legal entities of formal microfinance institution are a private business, cooperative or regional company, specifically for formal Islamic microfinance as referred to in Law No. 21 of 2008 Article 7 which stipulates that a legal entity is a private business. Supervision and guidance for formal microfinance institution are conducted by Indonesia Financial Services Authority (OJK). Formal microfinance institutions are classified into: Commercial Banks which have microfinance business unit (Bank of BRI Bank - Unit, and Bank of Mandiri (Micro Banking Unit), microfinance banks (Bank Perkreditan Rakyat) either under conventional or Sharia principle (BPRS). Thus, in Indonesia, conventional based microfinance is called Bank Perkreditan Rakyat (BPR), and microfinance institutions based on Islamic principles are called Bank Perkreditan Rakyat Syariah (BPRS). Both are categorized as formal microfinance institutions (Usman et al., 2004; World Bank, 2005; Indonesia Financial Services Authority,2018). Semi-formal microfinance institutions are those that are regulated by either central or regional government. The legal entities of semi-formal microfinance institution are a private business, the company's local government or regional government. Supervision and guidance for formal microfinance institution are done by the Financial Services Authority of Indonesia (OJK), and the Minister for Cooperatives Small and Medium Enterprises. Based on its institutional classification, informal microfinance are classified as Pawnshop, Village Credit Agencies (BKD), Social enterprises /Saving and Loan (S\&L) Cooperative (KSP), Social enterprises /Saving and Loan (S\&L) Cooperative (KSP), Baitul Maal Wa'atamwil (BMT). While the informal microfinance institutions are those that have no legal force as there is no specific regulation governing the matter (Baskara, 2013; Haryanto, 2011; Martowijoyo, 2000; Mujiono, 2013; Nelson, 2011; Susila, 2007; Usman et al., 2004; World Bank, 2005, Financial Services Authority of Indonesia, 2018). The classification of microfinance institutions in Indonesia is shown in Table 1.

\section{Indonesian Islamic Microfinance Bank}

One of the formal MFIs in Indonesia is a microfinance bank. According to Indonesian government regulation No. 10 of 1998, a microfinance bank is a bank that carries out its business activities either on a conventional (BPR) or on a sharia basis (BPRS) (www. bi.go.id). These types of formal microfinance banks provide such financial services to customers as savings, loans/credit, and deposits (Hamidi, 2017; Iswandari \& Anan, 2015; Yusi \& Idris, 2016). 
TABLE 1: Microfinance Institutions in Indonesia.

\begin{tabular}{|c|c|c|c|c|c|}
\hline & $\begin{array}{l}\text { Type of } \\
\text { Institution }\end{array}$ & $\begin{array}{l}\text { Business } \\
\text { License }\end{array}$ & Legal Entities & Guidance & Supervision \\
\hline \multirow[t]{2}{*}{$\begin{array}{l}\text { Formal } \\
\text { Microfinance } \\
\text { Institution }\end{array}$} & $\begin{array}{l}\text { Commercial } \\
\text { Banks with } \\
\text { microfinance } \\
\text { business unit } \\
\text { (Bank of BRI } \\
\text { Bank - Unit, } \\
\text { and Bank of } \\
\text { Mandiri } \\
\text { (Microbanking } \\
\text { Unit) }\end{array}$ & $\begin{array}{l}\text { FinancialService } \\
\text { Authority of } \\
\text { Indonesia } \\
\text { (OJK) }\end{array}$ & $\begin{array}{l}\text { Private } \\
\text { Business, } \\
\text { Cooperative or } \\
\text { Regional } \\
\text { Company }\end{array}$ & $\begin{array}{l}\text { Financial } \\
\text { Services } \\
\text { Authority of } \\
\text { Indonesia } \\
\text { (OJK) }\end{array}$ & $\begin{array}{l}\text { Financial } \\
\text { Services } \\
\text { Authority of } \\
\text { Indonesia } \\
\text { (OJK) }\end{array}$ \\
\hline & $\begin{array}{l}\text { Microfinance } \\
\text { banks (BPR) } \\
\text { either } \\
\text { Conventional } \\
\text { or } \\
\text { Shariah-based } \\
\text { namely Bank } \\
\text { Perkreditan } \\
\text { Rakyta Syariah } \\
\text { (BPRS). }\end{array}$ & $\begin{array}{l}\text { Financial } \\
\text { Services } \\
\text { Authority of } \\
\text { Indonesia } \\
\text { (OJK) }\end{array}$ & $\begin{array}{l}\text { Private } \\
\text { Business, } \\
\text { Cooperative or } \\
\text { Regional } \\
\text { Company. } \\
\text { "Particulary for } \\
\text { Islamic Microfi- } \\
\text { nanceBanks } \\
\text { (BPRS), The } \\
\text { legal Entity is a } \\
\text { Private } \\
\text { Business Refer } \\
\text { to (Law No. } 21 \\
\text { of 2008, Article } \\
\text { 7)" }\end{array}$ & $\begin{array}{l}\text { Financial } \\
\text { Services } \\
\text { Authority of } \\
\text { Indonesia } \\
\text { (OJK) }\end{array}$ & $\begin{array}{l}\text { Financial } \\
\text { Services } \\
\text { Authority of } \\
\text { Indonesia } \\
\text { (OJK) }\end{array}$ \\
\hline \multirow[t]{4}{*}{$\begin{array}{l}\text { Semi-Formal } \\
\text { Microfinance } \\
\text { Institution }\end{array}$} & $\begin{array}{l}\text { Perum } \\
\text { Pegadaian } \\
\text { (Pawnshop) }\end{array}$ & $\begin{array}{l}\text { Financial } \\
\text { Services } \\
\text { Authority of } \\
\text { Indonesia } \\
\text { (OJK) }\end{array}$ & $\begin{array}{l}\text { Private } \\
\text { Business, } \\
\text { Government } \\
\text { Regional } \\
\text { Company. }\end{array}$ & $\begin{array}{l}\text { Financial } \\
\text { Services } \\
\text { Authority of } \\
\text { Indonesia } \\
\text { (OJK) }\end{array}$ & $\begin{array}{l}\text { Financial } \\
\text { Services } \\
\text { Authority of } \\
\text { Indonesia } \\
\text { (OJK) }\end{array}$ \\
\hline & $\begin{array}{l}\text { Village Credit } \\
\text { Agencies (BKD) }\end{array}$ & $\begin{array}{l}\text { Financial } \\
\text { Services } \\
\text { Authority of } \\
\text { Indonesia } \\
\text { (OJK) }\end{array}$ & $\begin{array}{l}\text { Government } \\
\text { either central } \\
\text { and Regional }\end{array}$ & $\begin{array}{l}\text { Financial } \\
\text { Services } \\
\text { Authority of } \\
\text { Indonesia } \\
\text { (OJK) }\end{array}$ & $\begin{array}{l}\text { Financial } \\
\text { Services } \\
\text { Authority of } \\
\text { Indonesia } \\
\text { (OJK) }\end{array}$ \\
\hline & $\begin{array}{l}\text { Social } \\
\text { enterprises } \\
\text { /Saving and } \\
\text { Loan (S\&L) } \\
\text { Cooperative } \\
\text { (KSP) }\end{array}$ & $\begin{array}{l}\text { State Minister } \\
\text { for } \\
\text { Cooperatives } \\
\text { Small and } \\
\text { Medium } \\
\text { Enterprises }\end{array}$ & $\begin{array}{l}\text { Private } \\
\text { Business/Social } \\
\text { enterprises }\end{array}$ & $\begin{array}{l}\text { State Minister } \\
\text { for } \\
\text { Cooperatives } \\
\text { Small and } \\
\text { Medium } \\
\text { Enterprises }\end{array}$ & $\begin{array}{l}\text { State Minister } \\
\text { for } \\
\text { Cooperatives } \\
\text { Small and } \\
\text { Medium } \\
\text { Enterprises }\end{array}$ \\
\hline & $\begin{array}{l}\text { Baitul Maal } \\
\text { Wa'atamwil } \\
\text { (BMT) }\end{array}$ & $\begin{array}{l}\text { State Minister } \\
\text { for } \\
\text { Cooperatives } \\
\text { Small and } \\
\text { Medium } \\
\text { Enterprises }\end{array}$ & $\begin{array}{l}\text { Private } \\
\text { Business/Social } \\
\text { enterprises }\end{array}$ & $\begin{array}{l}\text { State Minister } \\
\text { for } \\
\text { Cooperatives } \\
\text { Small and } \\
\text { Medium } \\
\text { Enterprises }\end{array}$ & $\begin{array}{l}\text { State Minister } \\
\text { for } \\
\text { Cooperatives } \\
\text { Small and } \\
\text { Medium } \\
\text { Enterprises }\end{array}$ \\
\hline $\begin{array}{l}\text { Informal- } \\
\text { Microfinance } \\
\text { Institution }\end{array}$ & $\begin{array}{l}\text { NGO (LSM), } \\
\text { Shark Loan, } \\
\text { Rotating } \\
\text { Savings Club }\end{array}$ & $\begin{array}{l}\text { Does not have } \\
\text { legal force }\end{array}$ & $\begin{array}{l}\text { Does not have } \\
\text { legal force }\end{array}$ & - & - \\
\hline
\end{tabular}

Source: (Baskara, 2013; Haryanto, 2011; Martowijoyo, 2000; Mujiono, 2013; Nelson, 2011; Susila, 2007; Usman et al., 2004; World Bank, 2005; Indonesia Financial Services Authority,2018, Bank Indonesia, 2018) 
Both BPR and BPRS provide such financial services to customers as savings, loans/credit, and deposits (Hamidi, 2017; Iswandari \& Anan, 2015; Yusi \& Idris, 2016). Formal microfinance banks have not only profit orientation objectives but also to increase the income and the welfare of the people and to help increase economic empowerment and productivity of the community by facilitating credits to the poor and low-income people, especially micro, small and medium businesses (Indonesian government regulation No. 10 of 1998; Masyita, 2017; Mulyati \& Harieti, 2018). This means that BPR and BPRS have a system that operates almost the same which is based on profit in the context of financial sustainability, but in the social performance context, they have different characteristics from both BPR and BPRS. The social performance of BPRS not only includes the number of borrowing clients, the number of loans and savings accounts and the number of branches established, but also the integration of zakat, wakaf and qardlu hasan for rural and urban, which the performance of conventional microfinance institutions does not have (Fersi \& Boujelbéne, 2016; Mobin et al., 2017; Ahmed, 2002, Riwajanti, 2013).

According to Indonesian government regulation No. 10 of 1998, BPRS is a bank that conducts its business activities based on sharia principles. BPRS is fostered and supervised by the Financial Services Authority of Indonesia (OJK), and the legal entity of Islamic microfinance banks according to Law No. 21 of 2008, Article 7, which stipulates that the form of Islamic microfinance banks business is private where the capitals are obtained from internal and external investors.

Basically, BPRS has a system which is almost similar to the conventional rural bank operated on a profit basis. These institutions can earn profits in three areas, including trading, leasing, and direct financing from profit-loss sharing (PLS) contracts (Al-Omar \& Abdel-Haq, 1996). The products, services, and akad (contracts) used are different, however, all activities must be based on Islamic sharia law where riba, maysir, and gharar practices are prohibited. According to Chapra (1985), the term riba is commonly defined as taking extra profits from basic assets or capital. It is insubstantial because the owner of the fund requires the borrower to pay more than the borrowed funds irrespective that the borrower earns profits or experiences losses. Whereas "Maysir" literally means getting something very easily without hard work or getting profits without work. In Islam, maysir is anything that contains the elements of gambling, betting, or a risky game. Gambling in any form whatsoever is prohibited in Islamic laws (Hameed, 2009). As noted earlier in the Quran, Allah (s.w.t) clearly prohibits gambling (Al-Baqarah, 2:219 and Al-Maidah, 5:93). In Islam, gharar are all economic transactions involving the elements of obscurity, fraud or crime. It is condemned by Islam in the Qur'an (QS 6 152; 
83 1-5; and 4 29) and Hadiths. In the business world, gharar means blindly running a business with limited understanding (Rahmanti, 2012; Uddin, 2015).

\section{The Differences Between Conventional Microfinance Banks (BPR) and Islamic Microfinance Banks (BPRS)}

BPRS is not only a financial institution which serves a dual mission (financial and social) but also serves as a religious institution that runs its da'wah function (Wediawati, Effendi, Herwany, \& Masyita, 2018). The financial benefit provided by BPRS is to strengthen the Islamic economy, particularly weak economic community groups generally in rural and urban areas, and to increase the employment rate by developing Micro, Small and Medium-sized Enterprises (SMEs) with capital assistance from IMFIs (Amalia, 2009; Sumitro, 2002).

Both BPR and BPRS financial performance is associated with the return on equity (ROE), profit margin, return on asset (ROA), operational self-sufficiency (OSS), and financial self-sufficiency (FSS) (Schreiner, 2002; Rama, 2015; Hermes \& Hudon, 2018; Mobin, Masih, \& Alhabshi, 2017; Purwanto, Primiana, Masyita, \& Febrian, 2018; Wediawati et al., 2018). Social performance both BPR and BPRS are based on the average loan amount (relative to the income of the target population), the number of borrowing clients, the number of loans and saving accounts, the number of branches established and the share of loans to female borrowers are most often used (Hermes \& Hudon, 2018; Purwanto et al., 2018).

However, the differences between BPRS and BPR lie in their targeted organizational objectives. In BPRS, the organizational objective is based on shari'a principles (maqasid Sharia) which may lead to the balance of life (Falah) between worldly goals (financial and social goals) and hereafter goals (spiritual goal) in an expect to obtain blessings from the Almighty Allah SWT to run all organizational activities (Wediawati et al. 2018). Therefore, the financial BPRS performance puts more emphasis on profit and loss sharing based on mudharabah and musyarakah contract (Mobin et al., 2017; Purwanto et al., 2018; Wediawati et al., 2018). Musyarakah contract is a contract between two or more partners sharing both recent profits and losses. Instead of imposing interests as a creditor, the financier will receive a return based on a predetermined ratio in the form of a proportion of the actual profits earned. Unlike a traditional creditor, however, the financier will also share any losses. While mudharabah contract is a partnership in which one party provides the capital and another party provides labor force or skills. The capital provider is known as Rab Al-Mal, while the counterpart is known as the 
Mudarib. It is a trust contract, the mudarib is not liable for any losses except breach of trust (Fersi \& Boujelbéne, 2016).

The crucial part of the social performance is a provision of charity to the poor in which funds are obtained from zakat, wakaf and qardlu hasan, which the performance of conventional microfinance institutions does not have. These three funds serve as a charity instrument which occupies a central position in Islamic financial institution in terms of poverty eradication (Fersi \& Boujelbéne, 2016; Mobin et al., 2017). As a Shariabased financial institution, the objectives of BPRS must be consistent with the objectives of sharia principles (maqasid Sharia). These objectives will lead to the balance of life (Falah) between the worldly purposes (material / financial and social) and hereafter purpose (spiritual) in favor of Allah SWT (Wediawati et al., 2018). In other words, both financial performance and social performance are the objectives that must be achieved concurrently by BPRS (Abdelkader \& Salem, 2013; Fersi \& Boujelbéne, 2016; Mobin et al., 2017; Wediawati et al., 2018). The BPRS through Islamic financial instruments provides intermediary financial services by receiving funds from investors and other stakeholders on one hand and disbursing funds with or without profits to micro, small and medium entrepreneurs and poor households on the other hand. The basic model is needed to complete a full cycle of the Islamic microfinance process, namely: funding, an Islamic micro-finance institution, an Islamic financial instrument for disbursement of funds, the borrower, and the repayment. All these reasons make BPRS different from its conventional counterpart (Mobin et al., 2017).

In BPRS, Islamic charities such as zakat and waqf are special sources of funding. But if it is related to external funds, and the savings used as a source of funds, both from sharia and BPR are the same. Another specialty of BPRS is the financing mode that must eliminate interests in its operations while BPR adapts interest-based financing. Funding carried out by BPR is channeled to poor people in rural and urban areas with interests. While BPRS provide financing for poor people in rural and urban areas by integrating zakat. Another characteristic concern the transfer of funds by formal microfinance institutions. On BPR, institutions can directly provide cash to their clients as a form of financing. While service providers BPRS use goods transferred (murabahah). On the other hand, BPRS use Islamic financial instruments based on profit-sharing schemes instead of loans. While BPR target women as clients, whilst BPRS argue that the coverage should be targeted at all families members instead of just women. The characteristics and the difference between BPRS and BPR are summarized in Table 2. 
TABLE 2: The Differences Between Conventional Microfinance Banks (BPR) and Islamic Microfinance Banks (BPRS).

\begin{tabular}{|c|c|c|}
\hline & $\begin{array}{l}\text { Conventional Microfinance } \\
\text { Banks (BPR) }\end{array}$ & $\begin{array}{l}\text { Islamic Microfinance Banks } \\
\text { (BPRS) }\end{array}$ \\
\hline Liabilities (Source Of Funds) & External Funds, Saving of Client & $\begin{array}{l}\text { External Funds, Saving of client, } \\
\text { Islamic Charity Funds }\end{array}$ \\
\hline Asset (Mode of Financing) & Interest-Based & $\begin{array}{l}\text { Islamic Financial Instrument } \\
\text { (Profit and Low Sharing } \\
\text { approach) }\end{array}$ \\
\hline Financing the Poorest & Poorest In Rural and Urban Area & $\begin{array}{l}\text { Poorest are Included by } \\
\text { integrating zakah with } \\
\text { microfinancing in a rural and } \\
\text { urban area }\end{array}$ \\
\hline Fund Transfer & Cash given & Goods transferred (Murabahah) \\
\hline $\begin{array}{l}\text { Deduction at Inception of } \\
\text { Contract }\end{array}$ & $\begin{array}{l}\text { Part of the funds deducted at } \\
\text { Inception }\end{array}$ & No deductions at inception \\
\hline Target Group & $\begin{array}{l}\text { Family, Micro, and Small } \\
\text { Medium Enterprises (SMEs) }\end{array}$ & $\begin{array}{l}\text { Family, Micro, and Small } \\
\text { Medium Enterprises (SMEs) }\end{array}$ \\
\hline $\begin{array}{l}\text { The objective of Targeting } \\
\text { Women }\end{array}$ & Ease of Availability & Ease of Availability \\
\hline $\begin{array}{l}\text { Liability Of the Loan (When } \\
\text { Given to women) }\end{array}$ & Recipient and spouse & Recipient and spouse \\
\hline Work Incentive of Employees & Monetary & Monetary and Religious \\
\hline Dealing With Default & $\begin{array}{l}\text { Group/Central Pressure and } \\
\text { Threats }\end{array}$ & $\begin{array}{l}\text { Group/Centre/Spouse } \\
\text { Guarantee, and Islamic Ethics }\end{array}$ \\
\hline $\begin{array}{l}\text { Social Development } \\
\text { Programme }\end{array}$ & $\begin{array}{l}\text { Secular - behavioral, ethical } \\
\text { and social development }\end{array}$ & $\begin{array}{l}\text { Religious (Includes behavior, } \\
\text { ethics and social) }\end{array}$ \\
\hline Legal Entity & $\begin{array}{l}\text { Private Business, Cooperative } \\
\text { or Regional Company }\end{array}$ & $\begin{array}{l}\text { Private Business Refer to (Law } \\
\text { No. } 21 \text { of 2008, Article 7)" }\end{array}$ \\
\hline Guidance and Supervision & $\begin{array}{l}\text { Financial Services Authority of } \\
\text { Indonesia (OJK) }\end{array}$ & $\begin{array}{l}\text { Financial Services Authority of } \\
\text { Indonesia (OJK) }\end{array}$ \\
\hline Board of Supervision & $\begin{array}{l}\text { No Board of Syariah } \\
\text { Supervision }\end{array}$ & Board of Syariah Supervision \\
\hline
\end{tabular}

\section{Methodology}

This study uses documentary data to compare the performance of BPR and BPRS. The data was sourced from the Indonesian Services Authority (OJK) from 2012 until 2017. The financial performance is measured based on (i) Financing/credit, (ii) Profit, i.e, net income. These measures, i.e., profit and financing are used in other studies (see for example Masyita, 2017; Siti-Nazariah, Siti-Nabiha, \& Azhar, 2016; Ayayi \& Sene, 2008; Charitonenko \& Afwan, 2003; Asutay 2010; Kaplan \&Norton). Financial perspectives measure whether an organization's strategy, implementation, and execution are contributing to the organization improvement in general. 
Social performance is based on the measure of (i) Bank growth - Number of branches established and (ii) Number of customers. The measures used are similar to several other studies (see Fersi \& Boujelbéne, 2016; Hermes \& Hudon, 2018; Purwanto et al., 2018; Asutay 2010; Mersland \& Strom, 2009; Luzzi \& Weber, 2006). Social performance reflects the measure of the BPRS intention to have a social and feasible impact integration in the environment (Boye et al., 2006). This confirms that the role of social performance is to eradicate poverty in rural and urban areas (Fersi \& Boujelbéne, 2016).

\section{Result and Discussion}

The main activities of both BPR and BPRS are to serve SMEs and local communities in rural and urban areas (Trinugroho, Risfandy, \& Ariefianto, 2018; Yusi \& Idris, 2016). About $99 \%$ of the companies in Indonesia can be classified as SMEs (Shaban, Duygun, Anwar, \& Akbar, 2014). Therefore, formal microfinance banks either BPR or BPRS have a vital role in the current Indonesian economy (Trinugroho et al., 2018). The graphs show the difference between the credit/financing to customers by BPRS and BPR. The total credit/financing to customers from BPRS in 2012 is 2.080 Billion compared to the 23.749 Billion of BPR (see Figure 1). The BPR is currently the largest contributor in the credit/financing category for SMEs in Indonesia between 2012 and 2017. The percentage credit/financing of BPRS is from $8.52 \%$ to $9.35 \%$ of the total credit/financing of BPR in Indonesia between 2012 and 2017 (see Figure 2). It indicates that the total financing/credit accruing to the Islamic microfinance banks (BPRS) in Indonesia is lower than the Conventional microfinance banks (BPR).

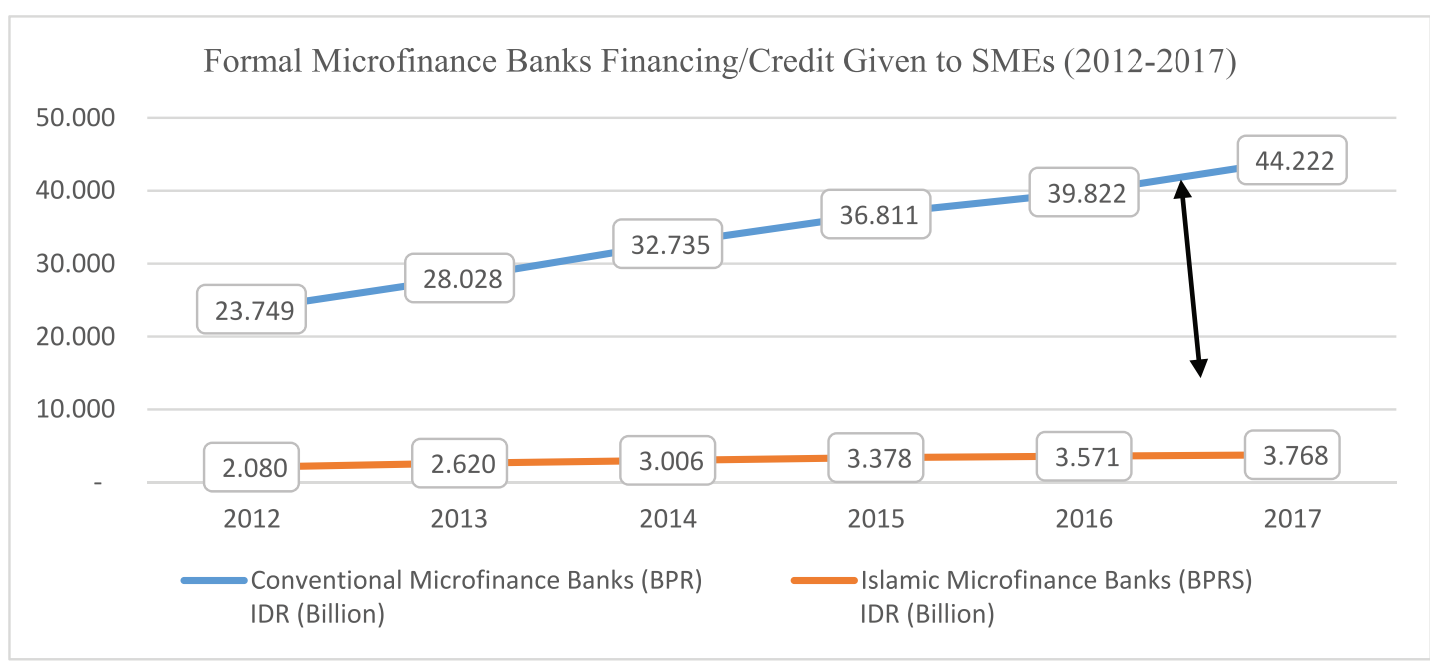

Figure 1: Formal Microfinance Banks Financing/Credit Given to SMEs (2012-2017) (Source: (Indonesia Financial Services Authority, 2018)). 


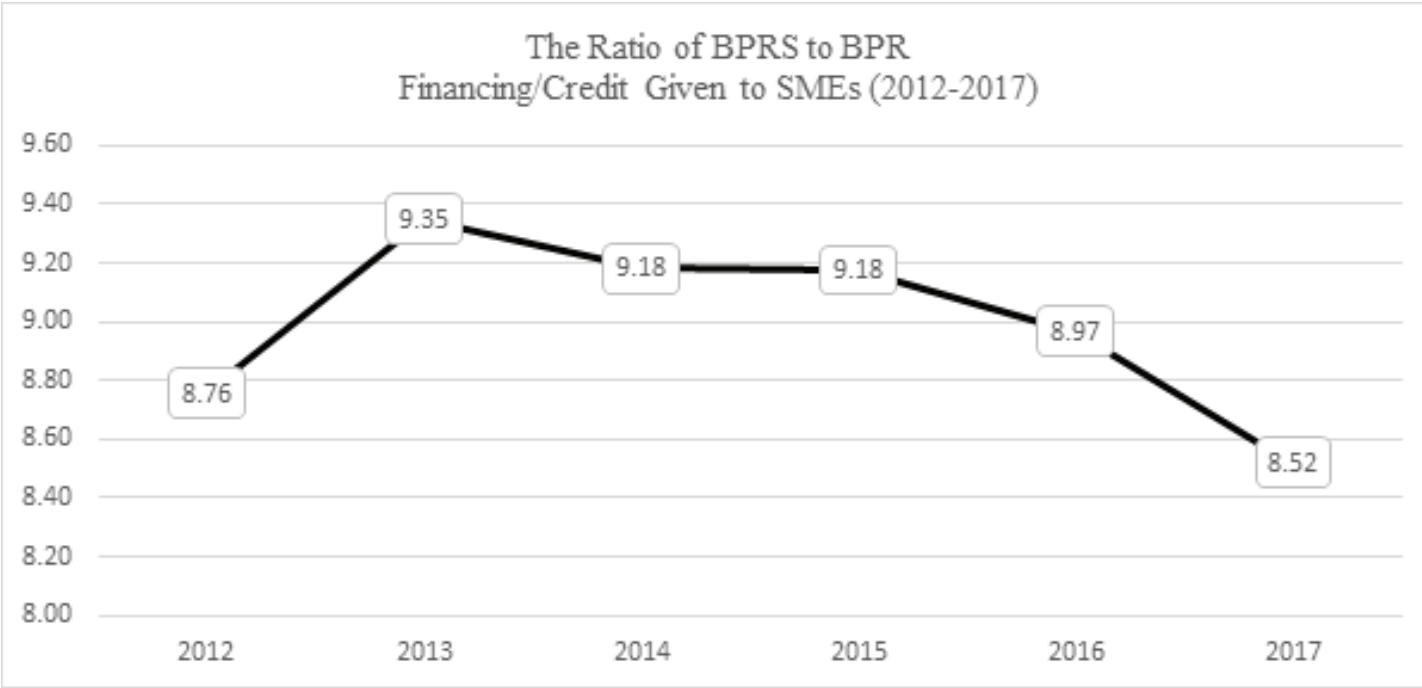

Figure 2: The Ratio of Islamic to Conventional Microfinance Banks (2012-2017) (Source: (Indonesia Financial Services Authority, 2018)).

Figure 3 shows the profitability for BPR and BPRS in Indonesia between 2012 and 2017. The profit of BPRS is 106 Million in 2012, rose to 129 Million in 2013, declined in 2014 and increased further in 2015 till 2017. However, the profit of BPRS from $4.55 \%$ to $6.64 \%$ of the total profit of BPR in Indonesia between 2012 and 2017 (see Figure 4.2). It indicates that the financial performance of BPRS from 2012 to 2017 is still far behind from BPR. This is supported by studies (Hamidi, 2017; Hanif et al., 2012; Wasiuzzaman \& Gunasegavan, 2013) which revealed that the financial performance of conventional microfinance banks is greater than that of Islamic microfinance banks.

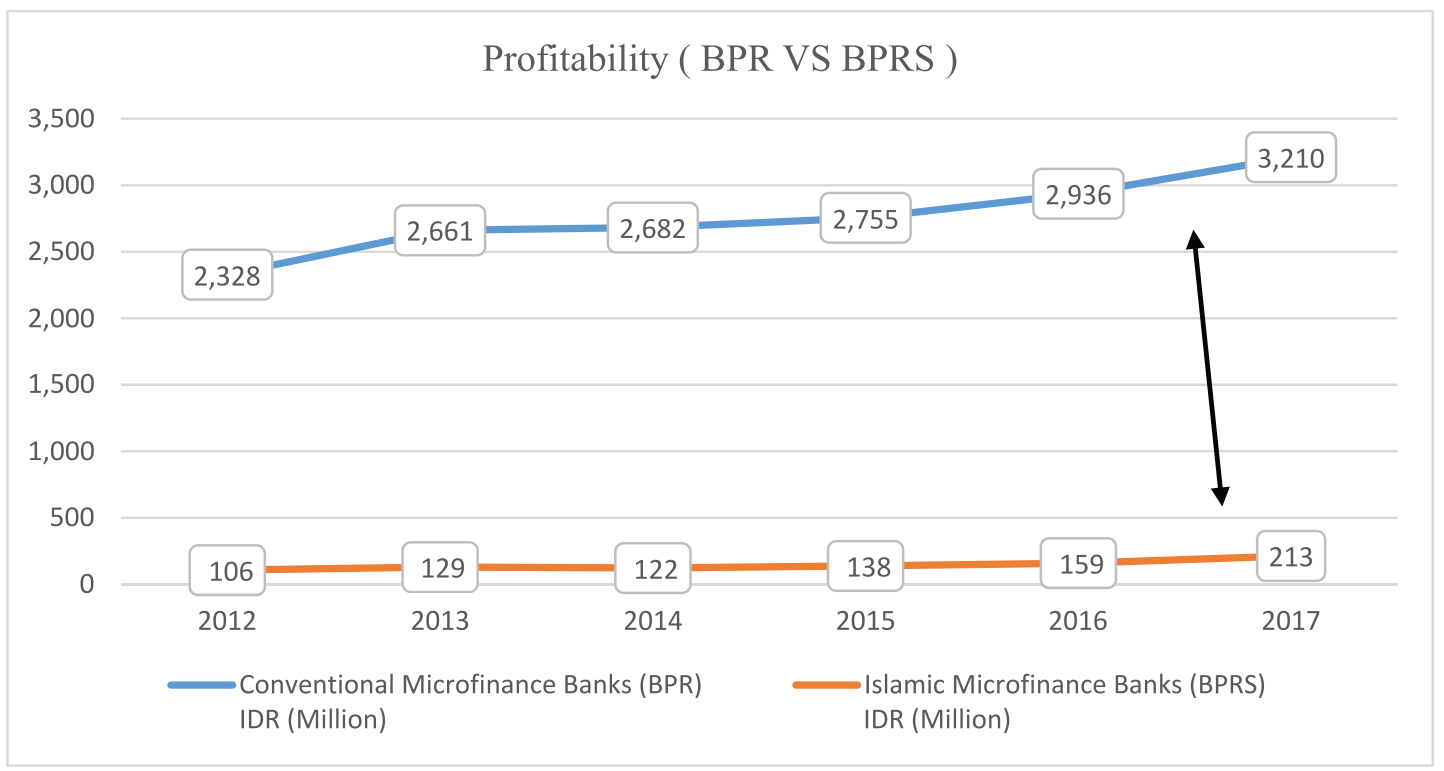

Figure 3: The Profit of Indonesian Formal Microfinance Banks (2012-2017) (Source: (Indonesia Financial Services Authority, 2018)). 
The Ratio of Profit of BPRS to BPR (2012-2017)

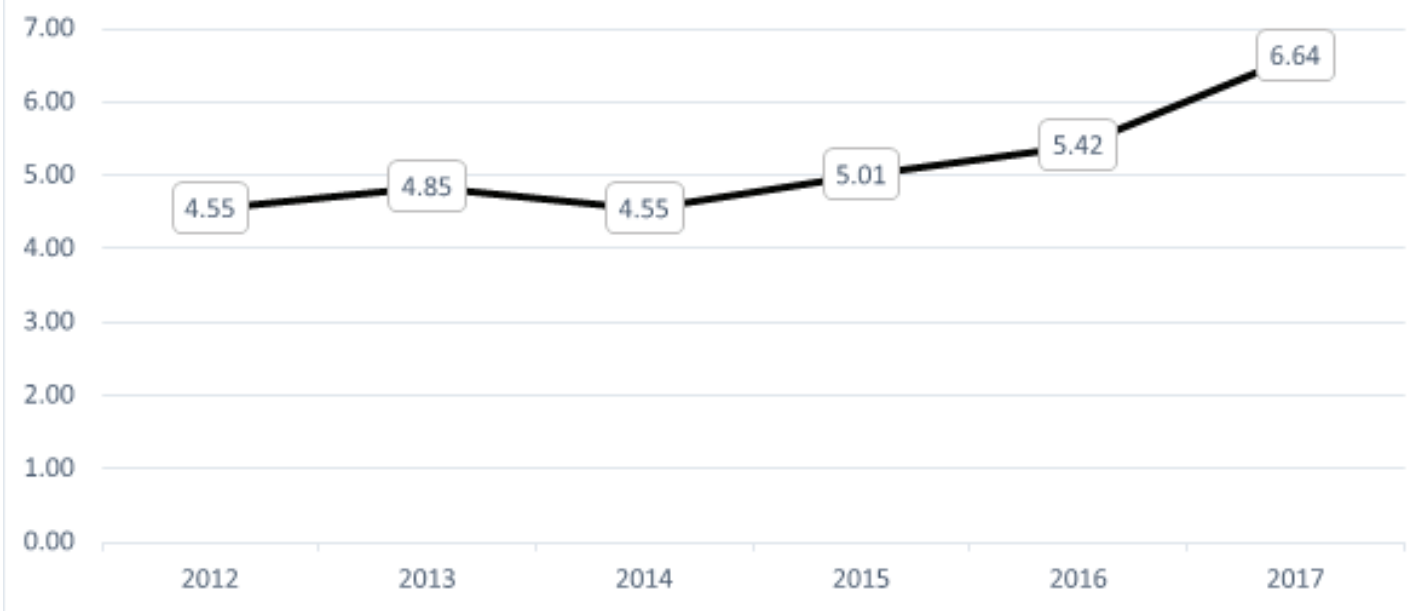

Figure 4: The Ratio of Profit of Islamic to Conventional Microfinance Banks (2012-2017) (Source: (Indonesia Financial Services Authority, 2018)).

Social performance, measured by the increase in the number of Islamic microfinance banks established is 158 in 2012, rose to 163 in 2013, stagnated in 2014, 2015, and increased further in 2016-2017 (Financial Services Authority, 2018). The number of BPRS represents approximately 10\% of BPR annually (Indonesian Financial Services Authority, 2018) (see Figure 5). This result indicates that Islamic microfinance banks (BPRS) have fewer numbers when compared to the number of conventional microfinance banks (BPR) established.

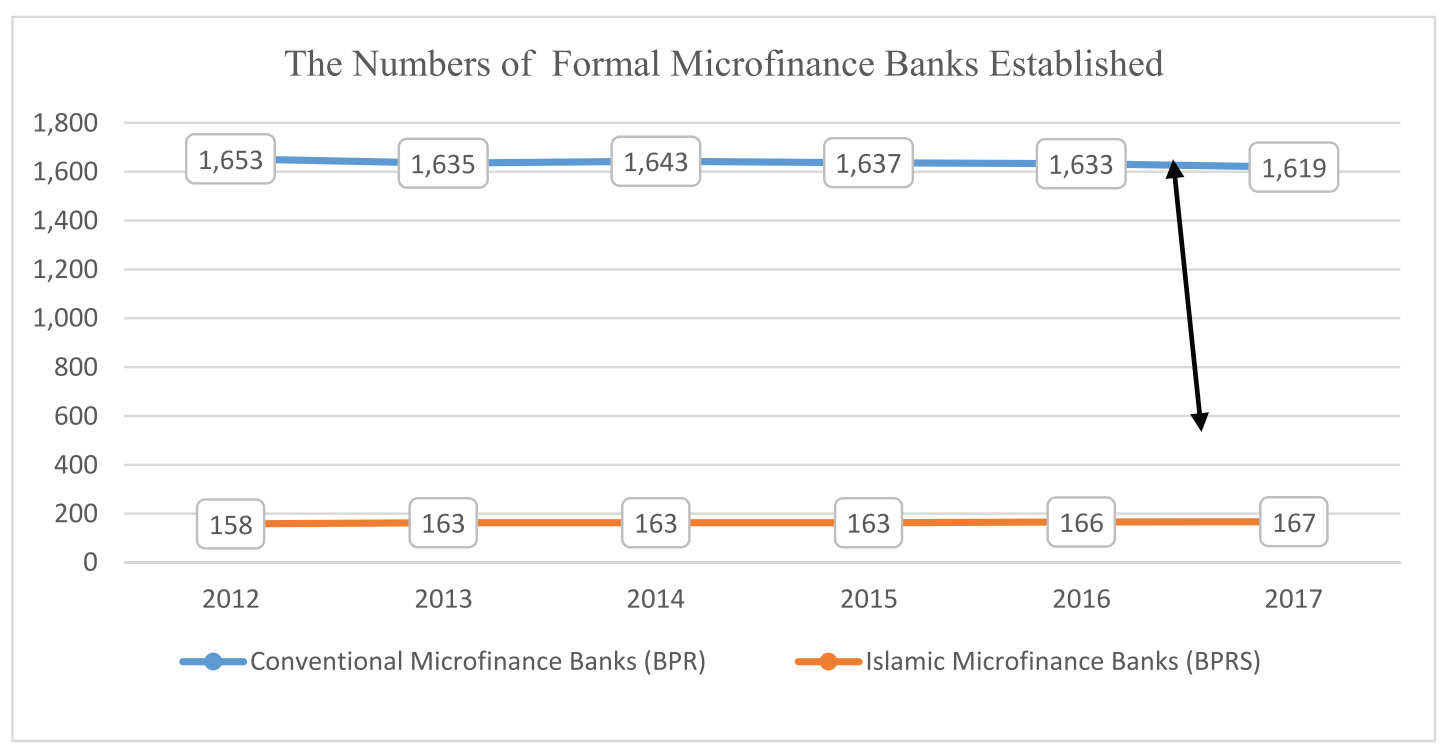

Figure 5: The Numbers of Indonesian Formal Microfinance Banks Established (2012-2017) (Source: (Indonesia Financial Services Authority, 2018)).

The other social performance is the number of formal microfinance banks customers. Figure 6 shows the difference between the number of customers by BPRS and BPR. The 
total customers from BPRS in 2012 are 789,923 compared to the 12,581,965 customers of BPR, in 2013 customers from BPRS is 907,755 compared to the $12,932,844$ customers of BPR. It indicates that the number of BPR customers compared to BPRS customers is the largest in Indonesia between 2012 and 2017. Figure 7 shows the ratio of customers in conventional and Islamic microfinance banks. The figure shows that there is an increasing trend in the number of customers for both BPR and BPRS. Results show that in 2012, the number of customers for BPRS is $6.26 \%$ of customers of BPR. It increased to $7.02 \%$ in 2013 , and increased further in $2014-2017$. This shows that the number of Islamic microfinance banks (BPRS) customers is far behind conventional microfinance banks (BPR).

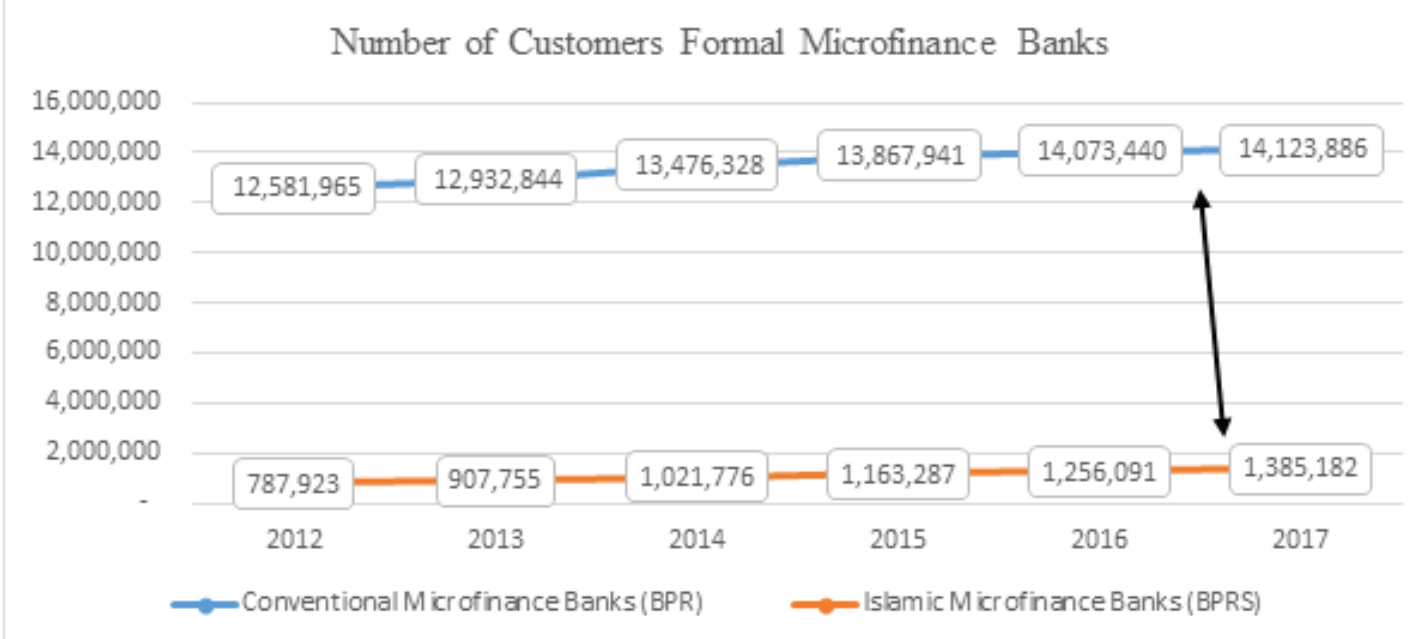

Figure 6: The Number of Customers of Indonesian Formal Microfinance Banks (2012-2017) (Source: (Indonesia Financial Services Authority, 2018; Indonesia Banking, 2018)).

The Ratio of Customers of BPRS to BPR (2012-2017)

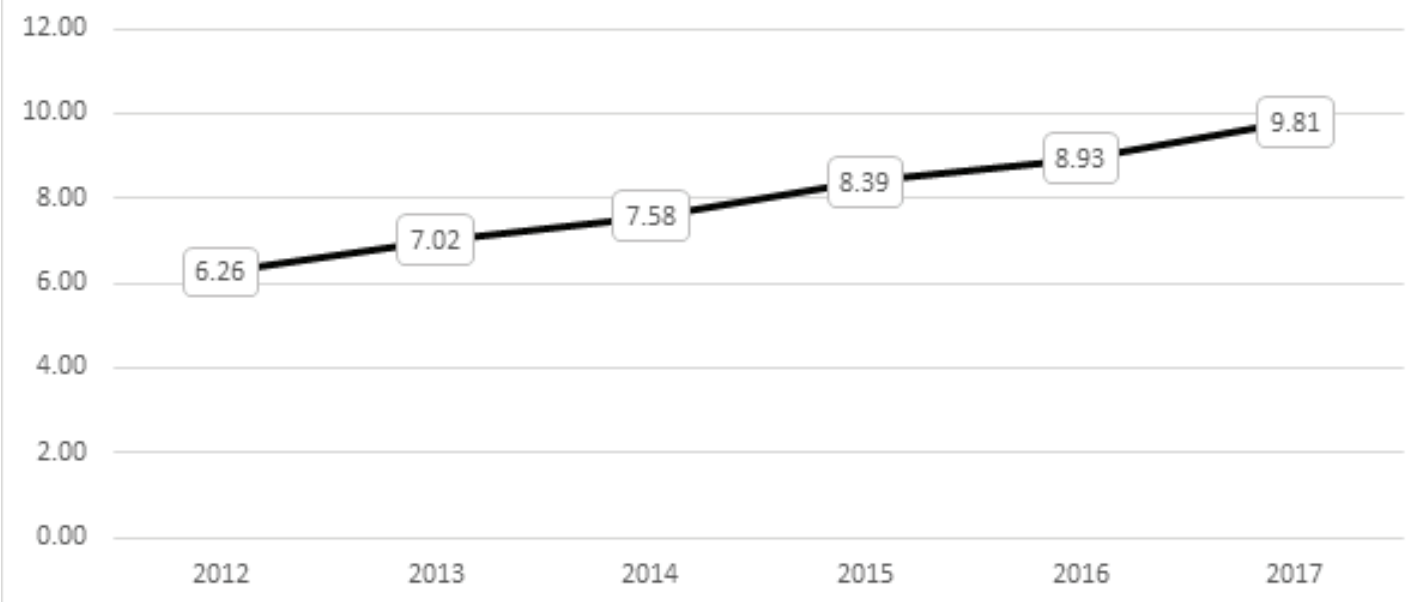

Figure 7: The Ratio of Islamic to Conventional Microfinance Banks (2012-2017) (Source: (Indonesia Financial Services Authority, 2018; Indonesia Banking, 2018)). 
Based on the data described above, Islamic microfinance banks have shown poor financial and social performance. Many researchers report similar findings that showed that the profitability of BPR is higher than that of BPRS (see for example Hamidi, 2017; Hanif, Tariq, Clean, \& Momeneen, 2012; Wasiuzzaman \& Gunasegavan, 2013). Moreover, several findings revealed that either the financial performance or social coverage of Islamic microfinance banks remains behind that of conventional banks.

Hence, there is a need to investigate the reason for such poor performance over the years. One avenue is to focus on corporate governance and internal mechanisms of BPRS as the insights of several studies have shown that poor performance is caused by problematic corporate governance (Hermes \& Hudon, 2018; Dian Masyita \& Ahmed, 2013; Seibel, 2008). Moreover, the lack of corporate governance is a critical problem in Islamic banks' performance as noted by Muliaman D. Hadad, the Indonesian Service Authority Board of Commissioners, as he stated in a speech in on $10^{\text {th }}$ of July 2017 :

"70\% of business closures of microfinance banks are caused by poor corporate governance and service."

Therefore, in order to improve organizational performance, especially that of the BPRS, good corporate governance is thus required. Microfinance practitioners stated good governance is of great importance because it is one of the keys to the success of both financial and social performance (Campion 1998; Rock et al. 1998; Labie 2001; CGAP 2006; Helms 2006; UN 2006; Arena, 2012; Varottil, 2012).

According to Hermes and Hudon (2018), governance refers to how rights and obligations are shared among stakeholders in an organization. This applies to who owns and manages the organism daily, and what mechanisms (internal and external) exist to ensure that stakeholder interests are safeguarded by the organization's administration. Therefore BPRS need a board of directors who are competence and experts in the Islamic financial field who can manage the organization, provide strategic direction and monitor the progress of the company with respect to the objectives set by the shareholders. Therefore, it is imperative to build the right processes, and policies within the organization, and to choose the right people to run the business. Therefore, with all these tasks and roles, determining the composition of the right board of directors in an organization should be done carefully (Niinikoski, 2018). This mean board composition in corporate governance is very important in improving performance in BPRS. As stated by Seibel (2008) who believes that if you want to improve performance in MFI you must increase competency and expertise (board composition) on the board of directors. 
In addition, the BPRS needs an effective Sharia Supervisory Board (SBB). SSB as an internal governance mechanism will encourage management to be transparent and have an impact on the institution's performance (Srairi, 2015). Thus, BPRS requires not only the Board of Directors' competence and expertise, but also SSB competence and expertise. Therefore, further research investigating BPRS governance should focus on both SSB and BOD. Based on Lan's findings (2012), it was found that protecting the interests of the investing public, maintaining confidence in the company and enhancing a country's global reputation as a trusted financial center would promote transparency and accountability. The two elements (transparency and accountability) in corporate governance can ensure activities of BPRS to be objective, professional, and can protect the interests of stakeholders so that it has an impact on improving the performance of these institutions (Augustine, 2012; Goddard 2005). It is, therefore, necessary to investigate BPRS elements and corporate mechanisms.

\section{Conclusion}

The data showed that BPRS's financial and social performance was poor compared to BPR for the five years from 2012 to 2017 . This problem must be addressed by the management and stakeholders. Increasing the effectiveness of BPRS governance can help them manage some of the challenges they faced today to improve their outreach and sustainability (Kassim, Hassan, \& Nadhirah, 2018). In addition, this will help BPRS achieve the dual baseline of balancing social goals with financial goals. However, this research has several limitations. The data explain only part of the financial and social performance, as it measures performance based solely on profit, financing, a number of borrowing clients and bank growth. Further research could include more holistic performance measures as financial and social performance in Islamic microfinance banks should also include profit and loss sharing (PLS) contracts, as well as the number of loans and savings accounts, and other more relevant measures of social performance. It is also suggested that further research could investigate corporate governance mechanisms which include board composition on BOD and SSB, and elements of corporate governance, such as transparency and accountability. The findings of this research could then provide a more practical recommendation and policy input to improve the governance and performance of BPRS in Indonesia. 


\section{Funding}

The authors would like to express their gratitude and appreciation to the Malaysian Ministry of Education for the funding of this research through the Fundamental Research Grant Scheme (FRGS): Grant No. 203.PPAMC.6711633.

\section{References}

[1] Abdelkader, I. Ben, \& Salem, A. Ben. (2013). Islamic vs Conventional Microfinance Institutions: Performance analysis in MENA countries. International Journal of Business and Social Research, 3(5), 219-233. https://doi.org/10.18533/ijbsr.v3i5.21

[2] Augustine, D. (2012). Good Practice in Corporate Governance: Transparency, Trust, and Performance in the Microfinance Industry. Business and Society, 51(4), 659-676. https://doi.org/10.1177/0007650312448623

[3] Ahmed, Habib, 2002, "Financing Microenterprises: An Analytical Study of Islamic Microfinance Institutions." Is/amic Economic Studies 9 (2): 27-64

[4] Al-Omar, F., and M. Abdel-Haq. 1996. Islamic banking: theory, practice, and challenges. London \& New Jersey: Zed Books. Al-Saud,

[5] Amalia, E. (2009), Keadilan distributif dalam ekonomi Islam. [A Distributive Justice in Islamic Economics], Raja Grafindo Persada, Jakarta

[6] Arena, T. (2012). Social corporate governance and the problem of mission drift in socially-oriented microfinance institutions. Columbia Journal of Law \& Social Problems, 41(3), 269-316. Retrieved from http://search.ebscohost.com/login.

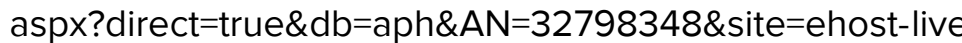

[7] Asutay, M. (2010). Islamic Banking and Finance and Its Role in the GCC-EU Relationship: Principle

[8] Ayayi, A. G., \& Sene, M. (2008). What drives microfinance institution financial sustainability. Finance, 1-39

[9] Baskara, I. G. K. (2013). Lembaga keuangan mikro di Indonesia (Microcredit institutions in Indonesia). Jurnal Buletin Studi Ekonomi, 18(2), 114-125. Retrieved from https://www.researchgate.net/publication/ 277813894_LEMBAGA_KEUANGAN_MIKRO_DI_INDONESIA

[10] Begum, H., Alam, A. S. A. F., Mia, M. A., Bhuiyan, F., \& Ghani, A. B. A. (2018). Development of Islamic microfinance: a sustainable poverty reduction approach. Journal of Economic and Administrative Sciences, JEAS-01-2018-0007. https://doi. org/10.1108/JEAS-01-2018-0007 
[11] Berguiga, I., Said, Y., Adair, P., Berguiga, I., Said, Y., \& Adair, P. (2017). The social and financial performance of Microfinance institutions in the MENA region: Do Islamic institutions perform better? To cite this version: HAL Id: hal-01667406.

[12] Boye, S., Hajdenberg, J., \& Poursat, C. (2006). Le guide de la microfinance: Microcrédit et épargne pour le développement. Paris: Edition d’Organisation, Groupe Eyrolles

[13] Campion, A. 1998. Current governance practices of mi- crofi nance institutions. Washington, DC: The Microfi nance Network. CGAP. 2006. Good practice guidelines for funders of Micro Finance. Available from Internet: <http://www.cgap.org/gm/ document-1.9.2746/donorguidelines.pdf $>$.

[14] CGAP (2007). CGAP Brief, Washington DC: CGAP, April 2007

[15] Fersi, M., \& Boujelbéne, M. (2016). The Determinants of the Performance and the Sustainability of Conventional and Islamic Microfinance Institutions. Economics World, 4(5), 197-215. https://doi.org/10.17265/2328-7144/2016.05.001

[16] Goddard, A. (2005). Accounting and NPM in UK Local Government: Contributions Towards Governance and Accountability“. Financial Accountability and Management, vol. 21, no. 2, pp. 191-214.

[17] Hamidi, M. (2017). Studi Komparasi Kinerja Bank Perkreditan Rakyat (BPR) Syariah dan Konvensional di Sumatera Barat. IQTISHADIA, Jurnal Kajian Ekonomi Dan Bisnis Is/am, 10(1), 44-70. https://doi.org/http://dx.doi.org/10.21043/iqtishadia.v10i1.2318

[18] Hameed, S. (2009). Accounting and Auditing for Islamic Financial Institutions. Kuala Lumpur: International Islamic University Malaysia

[19] Hanif, M., Tariq, M., Tahir, A., \& Momeneen, W. (2012). Comparative Performance Study of Conventional and Islamic Banking in Pakistan. International Research Journal of Finance $\{\&\}$ Economics, (83), 62-72.

[20] Haryanto, S. (2011). Potensi Dan Peran Lembaga Keuangan Mikro (Lkm) Dalam Upaya Pengembangan Usaha. MODERNISASI, 7(3), 229-238. https://doi.org/10.21067/jem. v7i3.192

[21] Helms, B. 2006. Access for all: Building inclusive fi nancial systems. Washington: CGAP

[22] Hermawan, H., \& Andrianyta, H. (2016). Lembaga Keuangan Mikro Agribisnis: Terobosan Penguatan Kelembagaan dan Pembiayaan Pertanian di Perdesaan. Analisis Kebijakan Pertanian, 10(2), 143. https://doi.org/10.21082/akp.v10n2.2012. 143-158 
[23] Hermes, N., \& Hudon, M. (2018). Determinants of the Performance of Microfinance Institutions: a Systematic Review. Journal of Economic Surveys, (October). https: //doi.org/10.1111/joes.12290

[24] Iswandari, M., \& Anan, E. (2015). Kinerja Keuangan Bank Perkreditan Rakyat Dan Bank Pembiayaan Rakyat Syariah: Studi Kasus Di Daerah Istimewa Yogyakarta. Jrak, $11,31-45$.

[25] Indonesia Banking Regulation; UU No.21 Tahun 2008 tentang Perbankan Syariah

[26] Jenita. (2017). Peran Lembaga Keuangan Mikro Syariah Dalam Pemberdayaan Ekonomi Masyarakat Kecil Menengah. Jurnal Lembaga Keuangan Dan Perbankan, 2(2), 178-191.

[27] Kaplan, R.S. and D.P. Norton. (1996) "Using The Balance Scorecard as a Strategic Management System." Business Harvard Review. 75-85

[28] Karim, N., Tarazi, M., \& Reille, X. (2008). Islamic microfinance: An emerging market niche. Focus Note, Consultative Group to Assist

[29] Kassim, S., Hassan, R., \& Nadhirah, S. (2018). Good Governance and Sustainability in Islamic Microfinance Institutions. Journal of Islamic Finance, 7(2), 21-28.

[30] Labie, M. 2001. Corporate governance in microfi nance or- ganizations: A long and winding road, Management Deci- sion 39: 296-301

[31] Lan, Luh Luh. 2012 "Goals of Cororate Governnce - A Singapore Perspetive" EU-Asia Corporate Governance dialoge, faculty of Law and NUS Business School, National University of Singapore. http://www.fsa.go.jp/frtc/kenkyu/event.Manan,

[32] Ledgerwood, A. 1999. Microfinance Handbook (Sustainable Banking with the Poor): An Institutional and Financial Perspective. World Bank Group.

[33] Littlefield, E., Morduch, J., \& Hashemi, S. (2003). Is Microfinance an Effective Strategy to Reach the Millennium Develoment Goals? Washinton D.C.: CGAP

[34] Luzzi, f. g., weber, s. (2006). Measuring the performance of Microfinance Institutions. Geneva: CRAG.

[35] Martowijoyo, S. (2000). Kinerja lembaga keuangan mikro dan perilaku masyarakat pedesaan. Buletin Ekonomi Dan Perbankan, 45-53.

[36] Masyita, D. (2017). Islamic microfinance institutions in Indonesia and the challenges in the supply chain perspectives. International Journal of Supply Chain Management, 6(4), 341-350. Retrieved from http://ojs.excelingtech.co.uk/index.php/IJSCM/article/ view/1951/pdf

[37] Masyita, D., \& Ahmed, H. (2013). Why Is Growth of Islamic Microfinance Lower Than Its Conventional Counterparts in Indonesia? Islamic Economic Studies, 21(1), 35-62. https://doi.org/10.12816/0000239 
[38] Mobin, M. A., Masih, M., \& Alhabshi, S. O. (2017). Religion of Islam and Microfinance: Does It Make Any Difference? Emerging Markets Finance and Trade, 53(7), 15471562. https://doi.org/10.1080/1540496X.2016.1268526

[39] Mujiono. (2013). Eksistensi lembaga keuangan mikro dan dampaknya terhadap sosial ekonomi masyarakat kabupaten bengkalis. Jurnal Inovasi Dan Bisnis, 4 No 2, 157171.

[40] Mulyati, E., \& Harieti, N. (2018). Model of business activities of microfinance institutions in Indonesia Model of business activities of microfinance institutions in Indonesia. IOP Conf. Series: Earth and Environmental Science 175.

[41] Mulawarman, A. D. (2009). Menggagas Lapor- an Keuangan Syari'ah Berbasis Trilogi Ma'isyah-Rizq-Maal. Tazkia Islamic Fi- nance \& Business Review, 4(1), 26-46

[42] Nelson, S. (2011). Performance Assessment of Microfinance Institutions In The Ashaiman Municipality by susuana nelson pg 3076009 A Thesis submitted to the Institute Of Distance Learning, Kwame Nkrumah University of Science and Technology in partial fulfillment of the requi, (June).

[43] Niinikoski, O.-M. (2018). Corporate Governance and Board Composition: diversity and independence of Australian boards. Aalto University School of Business Accounting. https://doi.org/10.1111/j.1467-8683.2007.00554.x

[44] Peraturan Bank Indonesia Nomor 11/23/PBI/ 2009 tentang Bank Pem-biayaan Rakyat Syariah. Peraturan

[45] Peraturan Bank Indonesia Nomor 15/3/PBI/ 2013 tentang Transaparansi Kondisi Keuangan Bank Perkreditan Rakyat.

[46] Peraturan Bank Indonesia Nomor: 8/18/PBI/ 2006 Tentang Kewajiban Penyediaan Modal Minimum Bank Perkreditan Rakyat.

[47] Peraturan Otoritas Jasa Keuangan No. 20/POJK.03/2014 tentang Bank Perkreditan Rakyat.

[48] Purwanto, Primiana, I., Masyita, D., \& Febrian, E. (2018). Social outreach model and efficiency in sharia micro finance institution: Literature review. European Research Studies Journal, 21(3), 104-122. https://doi.org/10.1007/s12665-013-2548-z

[49] Rahmanti, V. N. (2012). Sebuah Kajian Mengapa Akuntansi Syariah Masih Sulit Tumbuh Subur Di Indonesia. Jurnal Akuntansi Dan Investasi, 13(2), 161-179.

[50] Rama, R. and Taamrat, T.2015. Concepts and Measures of Outreach and Sustainability in Microfinance Institutions (A Comprehensive Literature Review). International Journal of Science and Research (IJSR), 4(2) 
[51] Reichert, P. (2018). A meta-analysis examining the nature of trade-offs in microfinance. Oxford Development Studies, 0818, 1-23. https://doi.org/10.1080/ 13600818.2018 .1427223

[52] Risfandy, T., Husa, P. P., \& Asrihapsari, A. (2016). Daya Saing Bank Syariah di Sebuah Negara Religius: temuan empirik dari indonesia. Jurnal Keuangan Dan Perbankan, 20(2), 282-291. https://doi.org/10.26905/

[53] Riwajanti, Nur Indah, \& Asutay,Mehmet.(2013).The Role of Islamic Microfinance Institution In Economic Development in Indonesia: A Comparative Analytical Empirical Study on Pre and Post States. Paper Presented in the $9^{\text {th }}$ International Conference on Islamic Economic and Finance (ICIEF).Istambu

[54] Robinson, Marguerite. 2001 “The Microfinance Revolution”. Lesson from Indonesia, Volume 2, pp. 352-354.

[55] Rock, R.; Otero, M.; Saltzman, S. 1998. Principles and practices of microfinance governance. Available from Internet:<http://www.gdrc.org/icm/govern/govern.pdf>. Sanda,

[56] Saeed A. Islamic banking and interest: a study of the prohibition of Riba and its contemporary interpretation. In: Studies law and society. Leiden: E.J. Brill; 1996.

[57] Schreiner, M. 2002. Aspects of outreach: a framework for discussion of the social benefits of microfinance. Journal of International Development, 14, 591-603.

[58] Seibel, H. D. (2008). Islamic Microfinance in Indonesia: The Challenge of Institutional Diversity, Regulation, and Supervision. Journal of Social Issues in Southeast Asia, 27(1), 54-83. https://doi.org/10.1355/s

[59] Shaban, M., Duygun, M., Anwar, M., \& Akbar, B. (2014). Diversification and banks' willingness to lend to small businesses: Evidence from Islamic and conventional banks in Indonesia. Journal of Economic Behavior and Organization, 103. https: //doi.org/10.1016/j.jebo.2014.03.021

[60] Siti-Nazariah, A. Z., Siti-Nabiha, A. K., \& Azhar, Z. (2016). Managing Social and Economic Performance in Social Enterprise: A Review of Literature. Qualitative Research Conference, 47-73. Retrieved from http://qualitative-research-conference. com/download/proceedings-2016/86-Nazariah436-445.pdf

[61] Srairi, S. (2015). Corporate governance disclosure practices of Islamic banks. Journal of Is/amic Finance, 4(2), 1-17.

[62] Susila, I. (2007). Analisis Efisiensi Lembaga Keuangan Mikro. Jurnal Ekonomi Pembangunan: Kajian Masalah Ekonomi Dan Pembangunan, 8(2), 223. https: //doi.org/10.23917/jep.v8i2.1043 
[63] Sumitro, Warkum. (2002). Asas-asas Perbankan Islam dan Lembaga Terkait (BMI dan Takaful di Indonesia). Jakarta: Raja Grafindo Persada

[64] "They ask you about wine and games of chance. Say: "In both these there is great evil, even though there is some benefit for people, but their evil is greater than their benefit" (Al-Qur’an: Al-Baqarah 2:219)

[65] ":There shall be no sin (imputed) unto those who believe and do good works for what they may have eaten (in the past). So be mindful of your duty (to Allah), and believe, and do good works; and again: be mindful of your duty, and believe; and once again: be mindful of your duty, and do right. Allah loveth the good" (Al-Qur'an: Al-Maidah 5:93)

[66] Trinugroho, I., Risfandy, T., \& Ariefianto, M. D. (2018). Competition, diversification, and bank margins: Evidence from Indonesian Islamic rural banks. Borsa Istanbul Review. https://doi.org/10.1016/j.bir.2018.07.006

[67] Tulchin, A. 2003. Micro Finance's Double Bottom Line. Working Paper to Develop New Sources of Capital. Social Enterprise Associates for the MicroCapital Institute, USA, 49.

[68] Uddin, M. A. (2015). Principles of Islamic Finance: Prohibition of Riba, Gharar and Maysir. Munich Personal RePEc Archive, (66085).

[69] United Nations. 2006. Building inclusive fi nancial sectors for development. Washington: United Nations.

[70] Usman, S., Suharyo, W. I., Soelaksono, B., Toyamah, Ni., Mawardi, M. S., \& Akhmadi. (2004).. HXDQJDQ OLNUR Keuangan Mikro untuk Masyarakat Miskin:

[71] Varottil, U. (2012). Microfinance and the corporate governance conundrum. SSRN Working Paper Series(Journal Article) 10.2139/ssrn.1986493. http://dx.doi.org/10. 2139/ssrn.1986493

[72] Wasiuzzaman, S., \& Gunasegavan, U. N. (2013). Comparative study of the performance of Islamic and conventional banks: The case of Malaysia. Humanomics, 29(1), 43-60. https://doi.org/10.1108/08288661311299312

[73] Wediawati, B., Effendi, N., Herwany, A., \& Masyita, D. (2018). Sustainability of Islamic Microfinance in Indonesia: a holistic approach. Academy of Strategic Management Journal, 17(3), 1-14.

[74] World Bank. (2005). Microfinance Case Studies: Indonesia's Rural Financial System - The Role of the State and Private Institutions. World Bank, 1-37. Retrieved from http://siteresources.worldbank.org/INTPGI/Resources/342674-1206111890151/ Microfinance_Indonesia.pdf 
[75] Yusi, M. S., \& Idris, U. (2016). Rural banking: The strategic solution in capital strengthening and performance of micro and small agribusiness enterprises in south Sumatera Indonesia. Journal of Internet Banking and Commerce, 21(2). 